\title{
Smiles in the Face of Nada
}

\section{Cruise Ships and D.F. Wallace's 'Experimental Essay،}

\author{
BURKHARDT WOLF
}

\begin{abstract}
$>$ Experience was a key moment in classical sea fiction. For it was first and foremost its ventures and undertakings, its discoveries and explorations that made seafaring a challenge for poetry and storytelling. But where can maritime writing begin after the sea, formely an elementary challenge, has become a crossroad of geopolitical interests and a medium of globalized economies? Cruise ships, for example, are floating adventure parks in which the traditional experience of the sea is virtualized and, in the mode of >thalassic regression<, integrated into the economy of the latest consumer and event capitalisms. In order to grasp the management and marketing of such maritime meta-experiences (including their >real flip side), a peculiar way of writing is required - less an old-style sea poetry than an experimental essayism, such as D.F. Wallace has tested it.
\end{abstract}

Title: Lächeln im Angesicht des Nichts. Kreuzfahrtschiffe und D.F. Wallaces >Erfahrungsbericht<

Keywords: seafaring; Wallace, David Foster (1962-2008); essay; economy; psychoanalysis

As an endless space of adventurous - and often dangerous - experience, the sea has always been a source of literary inspiration. However, in modernity and, a fortiori, in present times, maritime issues have substantially changed. For boat people and, maybe, for some fishermen and small-time smugglers, the sea is still a besetting »foe to man« (Melville 2000: 274), to quote Moby-Dick (1851). Instead of evoking sublimity, the sea now, to a large extent, is a space of opacity, a covert setting where global flows of capital and goods intersect, where military and political interests are at stake, and where new forms of value creation emerge (cf. İncirlioğlu 2011: 4of.). If, however, seafaring is no longer centered around the tenuous challenges of steering and communication, of technical and social organization - where exactly, then, is its place in contemporary writing? Modernist author Ernst Jünger considered seafaring and its disasters symptomatic of the state of Western culture - of its heroic struggle or, as in the case of the sinking Titanic, of its doom. With respect to the sea, »literature in the old sense« met its hour of death, Jünger stated in 1931. Henceforward, only »the objective field report« (>der sachliche Erfahrungsbericht<) could lead to something »significant.« (Jünger 1931: 16) 
Traditional and »out-of-time « sea narratives, of course, never thoroughly disappeared, since, in the field of maritime literature, there is a niche market for everything - especially for the nostalgic. But how are the peculiarities of contemporary seafaring, e.g. the living environment and >experiences < offered by its various types of vessels, reflected in writing? As for the particular case of refugee boats, numerous stories and novels (e.g. Abasse Ndione's Mbëkë Mi. A l'assaut des vagues de l'Atlantique, 2008) have been published; usually, and for good reason, they make use of the archetypal image of the sea as a space of frantic peril. Other novels chart coincidental encounters between refugee and rescue service boats, or of cruise and cargo ships, in a multi-perspectival manner, sometimes (as in Merle Kröger's crime thriller Havarie, 2015) using >factual< and >essayistic < means. With respect to tankships or containerships, - with their immense technical facilities and small crews -, there are, naturally, only rare examples of literary description; in Felicitas Hoppe's Pigafetta (1999), for example, such a ship is merely the starting point for a phantasmagorical time-travel journey, which reaches back to the Italian scribe Antonio Pigafetta who accompanied Magellan on his epoch-making journey. Indeed, what is available to crews on industrial vessels, largely deprived of any outside stimulation, contrasts especially starkly with the reality of another contemporary population at sea: the passengers on leisure cruisers, who are supplied with well-organized packages of >unforgettable experiences<. How are the experiences of this group reflected in literature?

Shortly before today's global cruising industry emerged, novels of classical modernity depicted the stay on liners in terms of outworn nautical metaphors: Against the background of its fantastic (or cryptopolitical) plot, in Julio Cortázar's Los premios (1960) the ship still serves as a symbol for the inevitably parlous formation of community, and for a course of life that is sidetracked and threatened by haphazardness. In more recent fiction, such as in Julian Barnes' A History of the World in 10 1/2 Chapters (1989), cruisers represent a closing chapter in the immemorial history of seafaring. But instead of describing the technical and economic, social and cultural peculiarities aboard, the novel shows the cruise ship (depicted in the image of the Achille Lauro) as a refuge of leisure and otiosity, being threatened from the outside, in this case by terrorist attacks. In contrast to previous adventurous or heroic experiences on ships, everyday experience on cruise ships seems to elude fictionalization - as if it were, as Jünger suggested, no topic for »literature in the old sense «. The aim of this paper, first, is to sum up the recent history of cruising tours; second, to investigate their broader cultural background; third, to examine the economy of contemporary cruising; and finally, to explore today's leisure cruisers as arenas for commercially >staged < and >second-order experiences - which call less for sea tales or sea poems than for analytic >field reports<. 


\section{1.}

Today's cruise industry has developed from several generations of precursors: from the first excursion voyages in the early $19^{\text {th }}$ century, from transatlantic travel around 1900, from the postwar boom (when a multitude of transport ships were available), and from its >post-modern < re-invention during the 1970s. The British Peninsula and Oriental Steam Navigation Company (P\&O) claims a pioneering role in the industry, running ships to Spain and China already in the early $19^{\text {th }}$ century (cf. Dickinson/Vladimir 2008: 2). P\&O stopped operations during the Crimean War, but resumed service once the British Medical Journal recommended sea voyages as remedies for several diseases. The main pioneer from a US-American perspective was Samuel Cunard, who took $\sigma_{3}$ passengers aboard his steamship Britannia for a transatlantic trip in 1840. Amongst the first cruising voyagers were writers such as Mark Twain and Guy de Maupassant, who used the ship as a vantage point from which to make a big literary haul. Particularly Twain portrayed cruise travel as a safe and untroublesome »grand picnic« (ibid.: 5), where dining, dancing and entertainment allowed for exceptional conviviality. In the long run, PQ广O and Cunard had set the pattern for liners (carrying either poor emigrants or upper class travelers) and for modern troop ships (serving during the World Wars).

When immigration policies became stricter after 1918 , the industry lost a vital source of income, forcing it to operate inventively. In the US, prohibition laws stimulated people to set out for a journey of alcoholic bliss; therefore, immigrant quarters were turned into bars and cocktail lounges. In Germany, companies like the Hamburg America Line generated some modest revenue by renting out their ships during winter seasons, or by refurbishing outdated vessels. They installed larger cabins or spacious public rooms, and painted the hull white, before heading to sunny regions. Already at that time, several lines had converted their inevitable repositioning trips into cruises, in order to turn operating costs into profit. Thus, the modern cruising business started as a kind of makeshift solution. Transatlantic travel boomed after 1945, peaking in 1957; however, in 1958, when PanAmerican began offering nonstop intercontinental jet flights, the liner business' upswing was decisively brought to a halt. Ever since, transatlantic journeys via ship have become, matter-of-factly, pretty useless. The ocean was to become an alley for tankships and container vessels - or, as in the case of outdated liner ships, the setting for mobile retirement homes for wealthy people in their nostalgic twilight years.

Things changed when Ted Arison founded Carnival Cruise Lines in 1972, an enterprise based around a new vision of nautical consumption. For this undertaking, he devised new on-board amenities and facilities within a refurbished former transatlantic liner and entered Caribbean cruising service in 1972. Carnival's so-called >Fun Ships < became the paradigm for self-centered, aimless ocean cruising, especially after they were advertised (for free) in the US Love Boat series, starting on TV in 1977 (cf. Vogel 2012: 119, 147). In the meantime, the business forged an alliance with its former adversary: Cruises now were sold together 
with airplane trips as »package vacations «. Since then, the industry has expanded in two main areas: in vessel size and in the extent of service and entertainment. Carnival built a one-thousand-passenger ship in 1982; today's largest cruisers are designed for almost 6,900 people. Carnival started the >Evolutions of Fun <refurbishment of its former >Fantasy-class fleet< in 2006; what had started as an entertainment program consisting of concerts or parlor games was extended to accommodate miniature golf courses or waterparks. Today, the cruising business boasts the largest growth rates in the tourist sector. In the 1970s, some 500,000 people took cruises; by 2001, there were almost 10 million; and in 2011, the number of cruising consumers exceeded 20 million for the first time. So, wherein lies the fascination with cruising? Since it seems to have no further purpose, is it in the undisguised experience of the sea?

2.

Since time immemorial, experiences at sea in the Western tradition have been tantamount to the challenge - or even defiance - of an elementary divide: the divide between land and sea. Land appeared as the natural resort for man: as the place where institutions are founded and where the nomoi (the basic natural, religious or political laws) apply. In contrast, the sea was held to be a primeval chaos, a gaping abyss, or, at the very least, a deterritorialized space hostile to man (as epitomized in Moby-Dick). Seafaring was considered a transgression, one calling for atonement and sin offerings to the gods. To prevent being devoured or being lost on the high seas, symbolic arrangements on ships were deemed as necessary for safety as navigational techniques of orientation. In every respect, the sea was regarded as a dangerous space. Therefore, the prototypical narrative of sea voyage, as laid out in the Odyssey, was a nostos, a story of homecoming, involving round-abouts and by-passes. Enduring and surviving such a journey was to be celebrated as a major personal - and, of course, also political and economic - achievement. Even if it expanded the former routes to global scale, early modernity's seafaring was in no way different: circumnavigating the world was an odyssey in its own right: it represented an enterprise of discovery and an investment in the unexpected, in imaginary or virtual new worlds. On these grounds, modernity's most famed maritime fictions (such as Defoe's or Melville's) were at the same time economic fictions. And on exactly these grounds, already early modern seafarers called themselves >adventurers<, identifying with this term in a threefold sense: first, as heroes who exposed themselves to the dangerous unknown; second, as participants in a venture, namely as bearers of risk; and, third, as sailors and traders without any certain route, following a kind of random walk, as unforeseen opportunities might pop up anywhere.

Legally, the high seas were considered an extraterritorial area, where ships represented floating territories. Therefore, the political status of the ship was disputed in modernity: It could be interpreted as a paradigm of free cooperation, with hierarchies in place primarily for functional reasons; or it could be or- 
ganized as a >ship of state < with rigid discipline and command structures. Ships were perfect examples of craftsmanship, routine and confidence, both in navigation and in leadership. »To deal with men is as fine an art as it is to deal with ships «, the sailor and author Joseph Conrad wrote. »Both men and ships live in an unstable element, are subject to subtle and powerful influences, and want to have their merits understood rather than their faults found out.« (Conrad 1995: IX, 27) According to Conrad, as long as the crew operated in accordance with its ship, seafaring constituted »a moral symbol of our life « (ibid.: XIX, 188). The introduction of steamship vessels, however, represented a sea change for the nature seafaring itself: ships and nautical traditions were made subject to huge corporate enterprises; seamen were replaced by industrial laborers like firemen or machinists, working under dismal conditions; purely technical hierarchies were installed; and the former >elementary sea< was transformed into a space subjected to economic and political power.

Nautical rules, skills and customs, as, for example, stowing the cargo, were dismissed. Within this context, ships transformed into mere transportation vessels, carrying industrial or human cargo, that is to say: masses of immigrants or travelers of luxury. »The whole psychology of sea travel is changed «, Conrad observed in 1926. »Formerly a man setting out on a sea voyage broke away from shore conditions and found in the ship a new kind of home. [...] The modern traveller has never the time to get into an acquiescent mood. The sham shore conditions which the shipping companies try to create for him stand in the way, too. The hold of the land (which is his natural element) is on him all through the passage« (Conrad 1926: 54f.). Ocean liners like the Titanic, according to Conrad »a sort of marine Ritz, [...] sent adrift with its casual population « (Conrad 1995: XIX, 227), were under the rules of landlocked mass democracies and their biopolitics: such ships' prime principle was security, and their passengers functioned as masses to be stowed and regulated, rather than as individuals to be hosted. In this way, modern sea traveling transposed the nomoi and rules of land onto the sea. The divide between land and sea lost its significance. And not only with respect to passenger ships: from an ecological point of view, tankships, those floating industrial islands, are as much a threat to the sea as the sea once was to earlier ships. And as the logistics of modern cargo-shipping requires the seamless transfer of standardized containers onto trains or, in turn, from trains to ships, the sea, economically speaking, is silted up and changed into land, while streams of commodities, of people, and of capital flood the whole globe.

\section{3.}

The >elementary sea < has largely disappeared from the perception of those at sea. On cruise ships, it has become an unnoticed or incidental backdrop, something to be used for brief periods of outdoor relaxation, while the ships' design shifts the centre of attention and experience to their interior: their amenities of fun, their mall areas and dining rooms. In a way, the maritime flows and streams 
have become virtualized and internalized. Indeed, »a motion-based virtual reality theater and a blue-screen room « has been part of cruise ships' basic equipment since 1997 (Dickinson/Vladimir 2008: 54). Cruise ships, therefore, are an economic showcase of what Zygmunt Bauman has termed our >liquid modernity<. Especially cruise ships from the 1970s onward exhibit a kind of »liquefaction« (Bauman 2000: 170; Papathanassis/Lukovic/Vogel 2012: 15) of seafaring's formerly firm social structures: they are resorts for average holidaymakers. In themselves, they are huge chunks of capital, being repositioned whenever prompted to by the weather, economic conditions, or political surroundings (cf. Dowling 2006: 398). They are symbols of our relentless nomadism, allowing us short-term visits wherever we like, while requiring minimal effort for our incessant traveling. In their permanent, but on the whole undirected course changes, those journeys have lost every notion of progress; and in their empty circularity, they exemplify our so-called postmodern condition: »not knowing the ends instead of the traditional uncertainty of not knowing the means « (Bauman 2000: 61). Accordingly, cruise ships take us nowhere, but they offer an agonizing range of choices. The whole world becomes a buffet table: full of possibilities, not a fraction of which could be realized. However, such freedom boils down to consumer choices, and for this life-style, there is, as it were, no sthere there (cf. Dowling 2006: 400). The cruising environment consists of non-lieux, of non-places and mere passages, of spaces without any symbolic expression of history, without opportunities for identity or any stable relations.

Time and again, Bauman describes >liquid modernity< and its economy through metaphors of water, invoking rivers or the sea. But cruising would be an even better case in point: its business typifies a deterritorialized capitalism held in place merely by transnational, dislocated corporations; and it makes use of a market for which there is no sthere< anymore, no holding power of local communities or labor force on capital (cf. ibid.: 398). Its economy, therefore, essentially consists of the international management of human resources. Particularly the global cruise business, as a showcase enterprise of globalized and neoliberal industry, benefits from legal, regulatory and taxation loopholes, from the economic dependencies of many destinations, and from the world labor market (cf. Papathanassis/Lukovic/Vogel 2012: 262). The monthly income of workers here is, more often than not, less than 1.000 or even 500 dollars for 18 to 20 working hours a day - without any vacation or days off for 10 consecutive months, and without any employment rights (cf. Klein 2002: 117; Dowling 2006: 377). Because, legally, every ship has to sail under a national flag, and because most Western countries established comparatively strict labor, safety and tax regulations, the cruising business, on an even larger scale than other maritime sectors, usually chooses so-called flags of convenience: of widely unregulated states like Monrovia or the Bahamas. Bob Dickinson, (former) President of Carnival, justified this practice without a bit of irony:

The problem is that most countries have labor unions and regulations that severely restrict the ability of a ship to staff itself with what may clearly be the optimal crew mix. 
[...] When a ship carrying an international crew is registered in Liberia or Panama, it is not subject to unions and other restrictive crewing policies. This means that owners are in a better position to negotiate fair and equitable compensation packages in a global free-market environment. (Dickinson/Vladimir 2008: 64)

On cruise ships, whose environment is not properly the sea but, rather, the globalized free-market, traditional nautical concepts won't work anymore. Cruise ships are neither units of free cooperation nor of stiff, state-informed discipline. They're also different from classic liners like the Titanic that were still directed at progress, even if, in the end, they exemplified nothing but progress's shipwreck. And apart from the waste streams they produce and effuse (cf. Krenshaw 2009: 143-145), cruise ships aren't floating cities, since they are unsteady and mobilized entities; they are not even hotels which would imply some local and traditional hospitality. Rather, they are amusement parks and shopping malls, floating resorts, or »floating apartheid machines of postmodern leisure « (Sekula 2002: 51), where technical workers look after a hidden infrastructure and emotional workers provide a fluid human façade. This latter group, these so-called >cast members $<$, are responsible for comfort and leisure, for sport and recreation, for entertainment and beauty, for health, therapy, and, obviously, shopping. Relying on severe security measures and precise controlling devices e.g. for detecting passengers fallen overboard and for crime investigation (cf. Papathanassis/Lukovic/Vogel 2012: 42), the business of the cruise ship is reduced to the management of fun and the provision of a so-called shigh-involvement product<, bringing about a >personal< attachment to the ship and its service.

Because new services, amenities, and offerings are invented for cruise ships every year, it would take far too long to enumerate only a part of them. This enormity of choice also baffles the cruising guests. »We all know «, Carnival president Dickinson says, »that folks can't possibly do everything that's offered. But that's not the point. They have the option, the choice, to be as active or passive as they wish.« (Dickinson/Vladimir 2008: 57) With this vast array of consumer options, cruisers enter a Disneyized realm (cf. Dowling 2006: 391f.), as it has been called: a realm where clear distinctions between different types of consumption disappear and where themed environments constantly promote the sale of merchandise. Enclosed in this consumerist space, the tourists provide a neat, laboratory-like opportunity for the company to study their choices, their tastes, and the behavior. Since the cruising industry is highly competitive, it constantly monitors its customers, and the customers are constantly asked to evaluate sthe product<. Most customers participate by themselves, as they provide >experience reports < and ratings on countless cruising websites. Through this feedback loop, the cruising business is able to optimize and adjust its products services and to develop strategies for stimulating new demands. At the same time, through their voluntary evaluations, customers involuntarily act as supervisors of the ship's employees, scrutinizing their service and their putative character.

Since there is no proper quality standard apart from consumer satisfaction, and since the consumers' only freedom is to be satisfied or to be unsatisfied, 
the core activity on board is the settlement of complaints. There is, of course, no proper procedure for this settlement; thus, complaints are usually dealt with informally, through compensation and emotional work most prominently expressed with constant smiles. As President Dickinson said: »Any crew member who receives a guest complaint >owns < that complaint. $\mathrm{He} /$ she is responsible for ensuring guest satisfaction. «(Dickinson/Vladimir 2008: 98) Or, to put it differently, any crew member is in custody of any consumer who might feel disoriented or even helpless. It is the duty of each employee to »[f]ind out what each guest wants « and to »[g]ive it to him or her.« (Ibid.: 99) Service employees are nannies, treating adults as children. In the end, the product that is offered by the cruise is an opportunity for regression: regression in service of the ego and to oral stages (as seen in the primary importance of food on cruises), and regression to cozy indulgence, while being under the protection of unconditional love. Consequently, service employees are usually forbidden to use the word >no < in conversations with their clients (cf. Dowling 2006: 394). Floating on an imaginary sea, being denied nothing, and being enclosed by a sheltering hull - in its essence, the cruiser's experience in the consumerist paradise closely resembles what Sigmund Freud and Sandor Ferenczi described as the »oceanic feeling « of regression and as a »thalassal regressive trend « (Freud 1999: 422; Ferenczi 1924: 70).

\section{4.}

Cruises have no use value as such; rather, »[t]heir value is expressed in experiential categories such as aesthetics, escapism, education (in a noninstrumental sense) and entertainment « (Papathanassis/Lukovic/Vogel 2012: 11). Or, as Dickinson says: »Affluent guests don't buy rooms or food or seats. They buy experiences.« (Dickinson/Vladimir 2008: 106) Initially, the term >experience was tightly linked to seafaring, because every maritime voyage was a dangerous enterprise, with discoveries to be expected, or with new knowledge to be collected. The Latin terms experientia and experimentum mean >adventure ril<, >experiment< and >personal experience $<$. Especially in nautical reports, >experience $<$ had a threefold sense: traveling a certain distance or reaching a certain destination (as manifest in the German term Er-fahrung); gaining empirical or experimental knowledge (as derived from the Greek synonym empeiria); and making personal observations and, therefore collecting expertise. The sexperience of seafaring was, from the outset, a domain of literary writing, insofar as literature made use of similar means and methods as travelogues (to name only the Odyssey), as scientific reports (e.g. in Moby-Dick), or as journals (think of Robinson Crusoe). But what about the peculiar sexperience< sold on cruise ships? In what way is it captured in writing?

In 1995, David Foster Wallace - whose work, up to his last novel The Pale King, focused again and again on experiential deficiency - was asked to write »a sort of really big experiential postcard « (Wallace 1997: 257) for Harper's magazine. To this end, he was invited on a seven-night-trip on the Carribean Cruiser Nadir. 
Right at the beginning, as if he just wanted to get it out of the way, he presents an evaluation of his experiences in the standard way: »The food was superb, the service impeccable, the shore excursions and shipboard activities organized for maximal stimulation down the tiniest detail. [...] The sun itself seemed preset for our comfort.« (Ibid.: 260) And so on. But by keeping his résumé forcefully precise - »I have in one week been the object of over 1500 professional smiles « (ibid.: 257) -, it turns into a report of his actual personal experience. And this experience, clearly, was far from uplifting: »Am I the only consumer in whom high doses of such a smile produces despair? «, he asks. »And yet the Professional Smile's absence now also causes despair«, be it only for »the humiliation and resentment of being denied the Professional Smile. [...] What a fucking mess.« (Ibid.: 289f.) What he almost never gets to see, is the putative reason for the whole enterprise: the sea. Mostly, just »a certain subtle unreality to your footing lets you know you're not on land « (ibid.: 283). The moment Wallace actually visualizes a proper seascape, »the sea is way below, and the sounds of it slopping and heaving around are far-away and surf-like, and visually it's a little like looking down into a flushing toilet.« (Ibid.: 279) And on the occasions he doesn't perceive the sea as only a kind of plumbing, he perceives »its unreal and almost retouched-looking prettiness - it's impossible to describe it quite right, but the closest I can come is to say it all looks: expensive.« (Ibid.: 306)

The sea disappears - and, finally, reappears as a product. It is virtualized and presented in the same manner as, for example, the countless painstaking wood imitations on the Nadir: they seem artificial and, simultaneously, more expensive than natural wood. >The real behind the enacted reality of cruising is encountered only as an exception, first of all at the moment of embarkation, when the travelers discover themselves as »Peregrinator americanus, Die Lumpenamerikaner. The Ugly Ones « (ibid.: 310); and when everything seems »as difficult and unpleasant as possible in order to sharpen the favorable contrast between real life and the $7 \mathrm{NC}$ experience.« (Ibid.: 270) >The real< is, so to speak, merely the remainder of the stage and scenery. Aboard, Wallace has to be truly imaginative to envision the miserable and pressing working conditions behind the employee's incessant self-explanations for their »cheery service« (ibid.: 266). He speculates about the enigma of the cabin service, because they clean up his room, every time he is away for 30 minutes or longer; but they leave everything untouched if he is away for 29 minutes and less; and they are never to be seen, even if he returns spontaneously after 29 and a half minutes. For Wallace, the only possible, but paranoiac explanation is the merging of an incredibly attentive service with panoptic surveillance - a cruiser-typical tight »passenger-satisfying interplay between people, processes and information systems infrastructure.« (Papathanassis/Lukovic/Vogel 2012: 77)

Wallace's text is neither fiction nor real-life comedy. The genre that probably fits best is the essay - a genre of semi-theoretical writing which, since its inception with Michel de Montaigne's and Francis Bacon's Essays, holds subjective experience and empirical knowledge in high esteem, examines these as means for ascertaining truth and hopes to produce this truth by itself in an sexperimen- 
tal< manner. As Adorno writes about the genre of the essay, here, »singularity's claim to truth is taken literally, up to the point where its untruth becomes evident «; and here, the »thinker does not actually think but rather makes himself into an arena for intellectual experience, without unraveling it.« (Adorno 1991: 13 a. 19) Against this background, Wallace' text is an experimental essay that tries to establish truth by exploring a singular case of untruthfulness (or calculated stupidity) for which his intellectual (or personal) experience serves as an arena. In the end, it attempts to reproduce this peculiar experience - that which makes it, in the broader sense, literary. But things are even more complicated, inasmuch as Wallace's experience concerns not only a >product that the cruising business tries to sell; the cruising business itself produces essays that reproduce the experiential product (and, as an ultimate twist, even offers Writer's Workshops to have such essays produced by the holidaymakers themselves). It's »a bona fide product«, Wallace writes about an onboard brochure,

it's supposed to be produced in you, this feeling: a blend of relaxation and stimulation, stressless indulgence and frantic tourism [...] that's marketed under configurations of the verb to pamper. [...] The brochure's real seduction is not an invitation to fantasize but rather a construction of the fantasy itself. [...] The promise is not that you can experience great pleasure, but that you will. [...] That they'll micromanage every iota of every pleasure-option so that not even the dreadful corrosive action of your adult consciousness and agency and dread can fuck up your future. [...] you will have no choice but to have a good time. (Wallace 1997: 260 a. 266f.)

Not only fantasies, but even interpretations of actual perceptions are addressed by such a »weird essaymercial« (ibid.: 288), so that all-encompassing care not only urges, but orders incapacitation. In this way, the essay becomes a »fantasyslash-promise of pampering in uterine stasis « (ibid.: 276), and the company's slogan »Your pleasure is our business« (ibid.: 267) gains a threefold meaning: it means, >Relax, we'll take care of everything <; it states, more literally, >Have fun, so we'll make good money<; and its third reading could be: »Mind your own bloody business and let us professionals worry about your pleasure, for Christ's sake.« (Ibid.)

As Wallace studies the course of his own, professionally stimulated desires, he captures their delusory dynamics. When the Nadir is docked in a harbor near the even bigger and more luxurious Dreamward, Wallace shows no interest for the ship and its technical aspects, let alone for the sea. But he starts »to feel a covetous and almost prurient envy of the Dreamward.« (Ibid.: 315) He imagines her as having a cleaner interior, a greater variety of food, bigger pillow mints, private balconies, less cheesy entertainment - and so on. He discovers »the Dissatisfied Infant part of me, the part that always and indiscriminately Wants« (ibid.: 316), and at the same time, he finds himself »anticipating just how totally stressful and demanding and unpleasurable regular landlocked adult life is going to be now « (ibid.: 317). But his exploration of »infantile narcissism« as »the dark heart of every human being « (Boswell/Burn 2013: 115) does not stop in this envious 
economic impasse. Just as already in Freud and Ferenczi - as well as in today's psychoanalysis (cf. Dolto 2003: 51-55) - infantile narcissism is linked to >thalassal< regression, and this >oceanic < feeling is traced back to a deeper anxiety: to the sudden awareness of a death drive that operates under our personal, cultural and, ultimately, economic struggles for safety and comfort.

Before returning from his seven-day-cruise, Wallace catches a glimpse of the sea itself. This, as he experiences it, »primordial nada« (Wallace 1997: 262), this gaping abyss of nothingness, this maw in which our everyday goals, desires and certainties are simply swallowed up, resuscitates the old image of the sea as the site of anxiety par excellence. Normally, this chasm is concealed by white and clean ship hulls flaunting »the Calvinist triumph of capital and industry over the primal decay-action of the sea « (ibid.: 263), by the incessant »construction of various fantasies « (ibid.: 263f.) and by endless palettes of choice. But catching a glimpse of the hidden side of cruising is like thwarting once and for all its obtrusively managed experience and its limitless commercial imagination - just to arrive at a stage where $>$ the real $<$, where groundlessness and nothingness puts the fear of God into us, and therefore drives us to care for more fundamental, for real choices. At last, the sea has turned back into an elementary or existential setting - yet only as the dark flipside of our delusions. No longer a space for open, though hazardous experiences, it has become a site for meta-experiences of regression and its concomitant death drive. Needless to say, this discovery is, for Wallace, something »unbearably sad «. But »like most unbearably sad things, it seems incredibly elusive and complex in its causes and simple in its effect« (ibid.: 261), which is why Wallace had to write his essay in the first place. Wallace cruise's outcome was a sad experience not only of lost ground - but also of a sea that may now itself be irredeemably lost.

\section{LITERATURE}

Adorno, Theodor W. (1991): The Essay as Form. In: Id.: Notes to Literature. Transl. from the German b. Shierry Weber Nicholsen. New York, S. 3-23.

Bauman, Zygmunt (2000): Liquid Modernity. Cambridge/Malden.

Boswell, Boswell/ Burn, Stephen J. (2013): A Companion to David Foster Wallace Studies. New York.

Conrad, Joseph (1926): Last Essays. London/Toronto.

Id. (1995): Collected Works. The Medallion Edition. London.

Dickinson, Bob/Vladimir, Andy (2008): Selling the Sea. An Inside Look at the Cruise Industry. Hoboken / New Jersey.

Dolto, Françoise (2003) : La vague et l'océan. Séminaire sur les pulsions de mort. Paris.

Dowling, Ross K. (ed.; 2006): Cruise Ship Tourism. Oxfordshire/Cambridge.

Ferenczi, Sandor (1924): Versuch einer Genitaltheorie. Leipzig/Wien/Zürich.

Freud, Sigmund (1999): Das Unbehagen in der Kultur. In: Id.: Gesammelte Werke. Ed. b. Anna Freud et al. Vol. 14. Frankfurt a.M., S. 419-506. 
İncirlioğlu, Güven/Topal, Hakan/Yavuz, Mahir Mustaf (2011): The Sea-Image. Visual Manifestations of Port Cities and Global Waters. New York.

Jünger, Ernst (1931): Über die Gefahr. In: Id.: Der gefährliche Augenblick. Eine Sammlung von Bildern und Berichten. Ed. b. Ferdinand Buchholtz. Berlin, S. 11-16.

Klein, Ross A. (2002): Cruise Ship Blues. The Underside of the Cruise Industry. Gabriola Island.

Krenshaw, Oliver G. (ed.; 2009): Cruise Ship Pollution. New York.

Melville, Herman ( $\left.{ }^{4} 2000\right)$ : Moby-Dick or The Whale. Ed. b. Harrison Hayford, Hershel Parker a. G. Thomas Tanselle. Evanston/Chicago.

Papathanassis, Alexis/Lukovic, Tihomir/Vogel, Michael (ed.; 2012): Cruise Tourism and Society: A Socio-Economic Perspective. Berlin/Heidelberg.

Sekula, Allan (2002): Fish Story. Düsseldorf.

Vogel, Michael (ed.; 2012): The Business and Management of Ocean Cruises. Oxfordshire/Cambridge.

Wallace, David Foster (1997): A Supposedly Fun Thing I'll Never do Again. In: Id.: A Supposedly Fun Thing I'll Never do Again. Essays and Arguments. New York/Boston/London, S. 256-353. 